\title{
Investigation of Vocational High School Students 'Views on Smart Phone Use: A Case Study
}

\author{
Ezgi Pelin Yildiz ${ }^{1} \&$ Ayşe Alkan ${ }^{1}$ \\ ${ }^{1}$ Kafkas University Computer Programming Department, Samsun Provincial Directorate of National Education, \\ Turkey \\ Correspondence: Ezgi Pelin Yildiz, Kafkas University Computer Programming Department, Samsun Provincial \\ Directorate of National Education, Turkey.
}

Received: May 24, 2019 Accepted: June 6, 2019 Online Published: June 25, 2019

doi:10.5539/hes.v9n3p45 URL: https://doi.org/10.5539/hes.v9n3p45

\begin{abstract}
The most preferred tools of technology today are internet and smart phones. Nowadays, these two tools offer numerous services and facilities to humanity in many areas. Accessing technology at any time, having a pleasant time, interacting without the limitations of face to face communication are some of them. That is why; individuals have become unable to live without internet and smartphones. Especially the rapid developments in information and communication technologies, internet and social media media, which is among the means of access to smart phones among university students and has made widespread use. In this context, a case study was conducted in order to examine the opinions of the students about the use of smart phones in Vocational High School students. For this purpose, the students' opinions were taken with a structured interview form. The questions in the interview form were developed by the researchers by conducting a comprehensive literature review. Expert opinion was consulted in the preparation of the interview form. The experts evaluated the suitability of the questions in terms of scope and language. The study group consisted of 10 students from the Department of Computer Programming and Computer Technology of Kafkas University. It is foreseen that the results of the research can lead to future scientific studies.
\end{abstract}

Keywords: smartphone, Vocational High School Students, case study

\section{Introduction}

The rapid developments in the technological field have brought about the development of mobile technological equipment. Mobile devices have eliminated the time and space limit, making users independent. Mobile phones, one of the most used mobile devices, have entered our lives since 1990 (Suler, 2016). With rapid advances in science and technology, mobile phones are replaced by smartphones. Smart phones are more preferred than mobile phones due to the fact that they can perform transactions with computers, have internet access, provide entertainment and social platforms through applications.

Advances in mobile technologies have enabled educators to send instructional messages in flexible ways. With new technologies including mobile computers, Pocket PCs, Apple iPhones, Android phones, and tablets, instructors and students can communicate through voice and image as well as text. Using mobile devices for educational purposes is becoming a common expectation of learners (Lan and Huang, 2012).

Mobile phones have become so ubiquitous that they turned into an important part of our life. According to Parsons, mobile subscriptions exceed 6 billion subscriptions globally. Similarly, Ipsos and Verizon (as cited in Tan and El-Bendary) found out that adopting mobile phones with smart technologies has increased fast which also coincided with a more utilization of their Internet capabilities.

Karaaslan and Budak (2012) stated that the purpose of the introduction of mobile phones in our lives is to be portable and provide the opportunity to communicate at any time. Coogan and Kangas (2001) also specify that smart phones are being replaced by computers as a result of easy portability. Ada and Tatlı (2013) also state that smart phones have become different from computers. In recent years, people's use of smartphones has started to change. Earlier communication and communication devices, smart phones are now being used for purposes such as connecting to the internet, social media, playing games, listening to music, making payments, banking and shopping (Meral, 2016). Furthermore, Townsend (2000) states that smartphones reduce their loneliness concerns 
because they provide social platforms and internet connection.

Smart phones are used by a large audience despite their high prices. With the motivation of using smart phones, there is a positive relationship between individual thought and practicality (Park and Chen, 2007).

In addition to the contribution of smart phones to our daily lives, there are also negative effects. For example; the use of uncontrolled smartphone may have negative physical and psychological effects on people and smartphone addiction may occur (Shata et al., 2016). According to Çakır and Oğuz (2017), although mobile phones have good aspects, they bring some physical, mental and behavioral problems.

Kwon et al. (2013) describe smartphone dependence as the behavior of constantly checking the phone. Demirci, Orhan, Demirdaş, Akpinar and Sert (2014) according to smart phone addiction, internet addiction, such as excessive use of people's daily lives are affected. Dependence on mobile phones in everyday life is referred to as nomophobia in psychology. Individuals with nomophobia are worried about losing their mobile phone and the mobile phone is disturbed when it is closed.

The negative effects caused by the use of smart phones: continuous display of the cause may cause headache, eye and concentration disturbance, face-to-face communication reduction, constant obsession with the screen can interfere with private life and cause problems such as stealing passwords (Soni et al., 2017; Oulasvirta et al., 2012; Unal, 2015).

Especially the rapid developments in information and communication technologies, smart phones, which are among the means of access to internet and social media environments, have become widespread and frequently used among university students. Unal and Arslan (2013) detected that the students of the faculty of education used their mobile phones intensively in their studies in order to compare the mobile phone usage frequency and brand preferences of the students studying at the faculties and foundations universities.

\section{Method}

This study was conducted with a case study design which is a qualitative research method. Case study; in fact, what is happening in the environment, systematically collecting data, analyzing and revealing the results (Davey, 1991). A case study is a research methodology that has commonly used in social sciences. General characteristics of case study according to PressAcademia, 2018;

- A case study is a research strategy and an empirical inquiry that investigates a phenomenon within its real-life context.

- Case studies are based on an in-depth investigation of a single individual, group or event to explore the causes of underlying principles.

- A case study is a descriptive and exploratory analysis of a person, group or event.

- A case study reserach can be single or multiple case studies, includes quantitative evidence, relies on multiple sources of evidence and benefits from the prior development of theoritical propositions.

- Case studies are analysis of persons, groups, events, decisions, periods, policies, institutions or other systems that are studied holistically by one or more methods.

\subsection{Study Groups}

The study group consisted of 10 students studying in the Department of Computer Programming and Computer Technology in Kafkas University.

\subsection{Data Collection Tool and Data Collection}

In this study, students' opinions were taken with a structured interview form. Relevant questions in the interview form were prepared by the researchers by conducting a comprehensive literature review. After the preparation of the form, expert opinion was consulted. 3 expert opinions were consulted on the linguistic suitability of the questions and the situation to be put forward. After the necessary corrections were made, the main interview form was obtained.

In addition in a structured interview form, where participants' confidentiality of information is kept confidential, an environment has been prepared to make them feel comfortable.

\subsection{Data Analysis}

In the analysis of the data, content analysis was used in accordance with the qualitative research method. Content analysis; It is a scientific approach and it provides an objective and systematic elaboration of verbal, written and other materials (Tavsanc1l \& Aslan, 2001).

After the content analysis, the findings were presented and interpreted. In addition, frequency tables were 
prepared for the opinions of the students of Vocational High School. Also, the results were evaluated in line with the opinions of the students.

\section{Findings and Comments}

The frequency tables of the responses of the Vocational High School students to the related questions in order to examine their views on the use of smart phones are summarized in Table 1 - Table 5. According to this;

Table 1. What is your reason for using a smartphone?

\begin{tabular}{ll}
\hline (n) & Codes \\
\hline Social media & 3 \\
Ease of communication & 3 \\
Getting Information & 2 \\
Internet Banking & 2 \\
Socializing & 2 \\
Communication & 1 \\
Adapt to era & 1 \\
Gathering Remembrance & 1 \\
Daily life facilities & 1 \\
\hline
\end{tabular}

According to the above table, it was determined that the reasons of using smart phones of Vocational High School students varied; however, it has been shown that the intensity is mostly on the use of social media and ease of communication.

Table 2. Which Applications Are Using Your Smart Phones

\begin{tabular}{ll}
\hline (n) & Codes \\
\hline Facebook & 10 \\
WhatsApp & 10 \\
Messenger & 10 \\
You Tube & 8 \\
Instagram & 7 \\
Twitter & 3 \\
Mobile Banking & 3 \\
E-government & 2 \\
Video Editor & 1 \\
PicsArt Photo Studio & 1 \\
\hline
\end{tabular}

Table 2 examined; the students used the applications they have listed in their smart phones as follows; facebook (10), whatsApp (10), messenger (10), you tube (8), instagram (7), twitter (3), mobile banking (3), e-government (2), video editor (1), PicsArt Photo Studio (1). Accordingly, the density; it is seen on facebook, whatsapp and messenger applications.

Table 3. What are the Advantages of Using the Applications on Your Smart Phones?

\begin{tabular}{ll}
\hline (n) & Codes \\
\hline Easy of communication & 10 \\
Speed & 8 \\
Information sharing & 8 \\
Time saving & 7 \\
Distance Education & 4 \\
Easy of internet banking & 3 \\
Spending time & 2 \\
Keep up to date news & 1 \\
\hline
\end{tabular}

When the table above is examined, the students listed the advantages of using the applications in their smartphones as follows; ease of communication (10), speed (8), information sharing (8), time savings (7), distance education (4), e-banking ease (3), spending time (2), follow current news (1). Accordingly, the density is in the area of ease of communication. 
Table 4. What Are the Changes in Your Daily Life without Smart Phones

\begin{tabular}{ll}
\hline (n) & Codes \\
\hline Interpersonal communication and chat would be better. & 3 \\
There was a lack of communication. & 2 \\
Leisure would be boring. & 2 \\
Information sharing would be reduced. & 2 \\
There would be no change. & 1 \\
The children started playing again in the streets. & 1 \\
\hline
\end{tabular}

When the table above is examined; it shows that communication and interpersonal communication are better. At the same time, children began to play in the streets again, such as internet addiction, aslogging, social escape brings to mind such negative perceptions.

Table 5. Do you think that the use of smart phones is harmful?

\begin{tabular}{ll}
\hline$(\mathrm{n})$ & Kodlar \\
\hline No & 1 \\
No & 1 \\
No & 1 \\
No & 1 \\
Yes & 1 \\
Yes & 1 \\
Yes & 1 \\
Yes & 1 \\
Undecided & 1 \\
Undecided & 1 \\
\hline
\end{tabular}

When the table above is examined, the question of whether the use of smart phones is harmful is 4 students no; 4 students answered yes and 2 students were hesitant. The reasons for those who say yes; triggering health problems (head, neck, back pains, etc.) when used for long hours, radiation propagation, especially when they think that they reveal the problem of game addiction for children, people prefer virtual communication rather than face-to-face conversations, and this situation is perceived as thinking it was. Unstable students in general as the positive aspects of smart phones; and that they also have negative effects such as dependency and asocialisation.

\section{Conclusion and Discussion}

The results of this study, which examines the opinions of the Vocational High School students about the use of smart phones, are as follows;

The reasons why students use smartphones; to adapt to the era, communication, gathering remembrance, social media and internet banking, socialization, getting information, ease of communication and daily life facilities under the headings. In this research question, it was found that the intensity was on social media usage and ease of communication. When the field is examined in literature, similar to the research; Icirgin (2018) aims to determine the social media usage habits and motivation of university students. As a result, it was revealed that social media usage habits and motivations of university students were quite high. In a study conducted by Kucukali (2016) in which university students investigated social media use; it was determined that the students used social media intensively and also the cultural structure, kinship and friendship relations were determined in the background of this density.

Students use applications on smartphones; Facebook, twitter, instagram, whatsapp, mobile banking, messenger, e-government, video editor, PicsArt Photo Studio as explained. The density is mostly; Facebook, You Tube, WhatsApp and Messenger applications are found to be on. This result supports that vocational high school students use social media intensively. Kecel and Seferoğlu's research (2017) conducted an assessment of the educational use of mobile technologies and applications and worked with 40 volunteer teachers. Similarly, the results of the teachers' frequent use of the related practices have been put forward. Students benefit from smartphones; speed, time saving, ease of communication, information sharing, distance education, ease of e-banking, spending time and keep up to date news evaluated the current news under the headings. In their study Bulduklu and Özer (2016), they examined the motivation of young people to use smartphones; as a result, it has 
been found that young people find the smart phones useful in terms of socialization / access to information, entertainment, technology and developments, and the sense of trust provided by the phone.

There are many different answers to the question of what would be the changes in daily life if the students were not smartphones, there are also topics that will support the use of the smartphone in a positive and negative topic. The density is; "interpersonal communication and chat would be better" on the title. This intensity supports the negative aspects of smartphones.

Similar to the results of the research; Yusufoğlu (2017) as a leisure activity on smartphones and their effects on social life: as a result; found that students support the view that technology does not make individuals happy and increases the longing for past. Finally, students have given a wide variety of answers to the question of whether you think smartphone use is harmful, no, yes, undecided; no and yes responses were found to be the same in the study. The reasons for those who say yes; triggering health problems when long hours are used (head, neck, back pains, etc.), radiation spread, especially for children to think about the problem of game addiction, people prefer to face virtual communication rather than face-to-face communication and this situation brings along asocialization. Undecided students in general as the positive aspects of smart phones; and that they also have negative effects such as dependency and asocialisation. Students who are undecided are the positive aspects of smartphones such as; speeding up communication and information sharing and but they also stated that there are also negative effects such as dependency and asocialization. In particular, the answers to this research question bring to mind the negative concepts such as smartphone addiction, asocialization and social escape. Taylan (2016), in his research, investigated the addiction of smartphones in higher education students and as a result; half of the students were normal phone users, and 39\% of them reported that they had a risk of smartphone addiction. Minaz et al., (2017) found that students' level of smartphone addiction was 90.25\%. Chen et al., (2011) aimed to investigate the prevalence of smartphone addiction and factors associated with boys and girls in their research. 1441 undergraduate students from China's Wannan Medical College were included in the study. A short version of the smartphone addiction scale, depression, anxiety and sleep quality scales were applied to the participants. A significant relationship was found between male students 'game applications, worry and poor sleep quality factors and female students' game applications, worry and poor sleep quality factors.

\section{Acknowledgements}

This study is presented as an oral presentation by us to World Conference on Educational Technology Researches (WCETR) 2019 ANTALYA in TURKEY.

\section{References}

Ada, S., \& Tatlı H., S. (2013). Akıllı telefon kullanımını etkileyen faktörler üzerine bir araştırma. Retrieved from http://ab.org.tr/ab13/bildiri/74.pdf

Bulduklu, Y., \& Özer, N., P. (2016). Gençlerin Akıllı Telefon Kullanım Motivasyonları. https://doi.org/10.15869/itobiad.265374

Chen, K., Chen, J. V., \& Yen, D., C. (2011). Dimensions of self-efficacy in the study of smart phone. Computer Standards \& Interfaces, 33(2011), 422-43. https://doi.org/10.1016/j.csi.2011.01.003

Coogan, K., \& Kangas, S. (2001). NuoretJaKommunikaatioakrobatia, 16-18 Vuotiaiden Nuorten K. Annykk. A-Jaİnternetkulttuurit. NuorisotutkimusverkostoJa Elisa Ommunications. Elisatutkimuskeskus. Raportti 158.

Çakır, Ö., \& Oğuz, E. (2017). Lise Öğrencilerinin Yalnızlık Düzeyleri İle Akıllı Telefon Bağımlılığı Arasındaki İlişkisi. Journal of Mersin University Education Faculty, 13(1), 418-429. https://doi.org/10.17860/mersinefd.290711

Demirci, K., Orhan, H., Demirdas, A., Akpınar, A., \& Sert, H. (2014). Validity and Reliability of the Turkish Version of the Smartphone Addiction Scale in a Younger Population. Bulletin of Clinical Psychopharmacology, 24(3), 226-234. https://doi.org/10.5455/bcp.20140710040824

İçirgin, Ö. (2018). Üniversite öğrencilerinin sosyal medya kullanım alışkanlıkları ve motivasyonlar. Published Master Thesis. Selcuk University Social Sciences Institute.

Karasar, N. (2005). Bilimsel Araştırma Yöntemi. (14 ${ }^{\text {th }}$ Edition). Nobel Publishing Distribution, Ankara.

Karaaslan, A. İ., \& Budak, L. (2012). Üniversite Öğrencilerinin Cep Telefonu Özelliklerini Kullanımlarının ve Gündelik İletişimlerine Etkisinin Araştırılması. Journal of Yaşar University, 26(7), 4548-4525.

Keçel, N., \& Seferoğlu, S. S. (2017). Mobil Teknoloji ve Uygulamaların Eğitsel Kullanımına Yönelik Bir 
Değerlendirme. $11^{\text {th }}$ International Computer and Instructional Technologies Symposium (ICITS-2017) 24-26 Mayıs 2017, Inönü University, Malatya.

Kurt, F. (2018). Üniversite Öğrencilerinde Akıllı Telefon Kullanım Bozukluğu ile Dürtüsel Davranışve Çocukluk Çağı Travması Arasındaki İlişkisi. Master Thesis, Uskudar University, Social Science Institute, Istanbul.

Küçükali, A. (2016). Üniversite Öğrencilerinin Sosyal Medya Kullanımı: Atatürk Üniversitesi Örneği. Bartın University Journal of I.I. ..B.F., 7(13), 531-546.

Kwon, M., Kim, D. J., Cho, H., \& Yang, S. (2013). The smart phone addiction scale: development and validation of a short version for adolescents. PloSone, 8(12), e83558. https://doi.org/10.1371/journal.pone.0083558

Lan, Y.-F., \& Huang, S.-M. (2012). Using mobile learning to improve the reflection: a case study of traffic violation. Educational Technology \& Society, 15(2), 179-193. Retrieved from http://www.ifets.info/journals/15_2/16.pdf

Meral, D. (2017). Orta Öğretim Öğrencilerinde Akıllı Telefon Bă̆ımlılığının Yalnızlık, Yaşam Doyumu Ve Bazı Kişisel Özellikler Bakımından Incelenmesi. Master Thesis Erzincan: Erzincan University. Social Science Institute.

Minaz, A., \& Bozkurt, Ç. Ö. (2017). Üniversite Öğrencilerinin Akıllı Telefon Bağımlılık Düzeylerinin ve Kullanım Amaçlarının Farklı Değişkenler Açısından İncelenmesi. Mehmet Akif Ersoy University Journal of Social Science Institute, 9(21), 268-286. https://doi.org/10.20875/makusobed.306903

Oulasvirta, A., Rattenbury, Y., Ma, L., \& Raita, E. (2012). Habits Make Smartphone Use More Pervasive. Personal and Ubiquitous Computing, 16(1), 105-114. https://doi.org/10.1007/s00779-011-0412-2

Park, Y., \& ve Chen, J. V. (2007). Acceptance and adoption of the innovative use of smartphone, Industrial Management \& Data Systems, 107(9), 1349-1365. https://doi.org/10.1108/02635570710834009

PressAcademia, (2018). Definition of Case Study. Retrieved from https://www.pressacademia.org/definition-of-case-study/

Punch, F. K. (2005). Sosyal araştırmalara giriş nitel ve nicel yaklaşımlar. (D. Bayrak, H. B. Arslan, and Z. Akyüz, Trans.). Ankara: Siyasal Bookstore.

Soni, R., Ritesh, U., \& Mahendra, J. (2017). Prevalence of Smart Phone Addiction, Sleep Quality And Associated Behaviour Problems in Adolescents. International Journal of Research in Medical Sciences, 5 , 515-519. https://doi.org/10.18203/2320-6012.ijrms20170142

Süler, M. (2016). Akıllı Telefon Bağımlıllğının Öznel Mutluluk Düzeyine Etkisinin Çeşitli Değişskenler Açısından Incelenmesi. Published Master Thesis. Sakarya: Sakarya University Education Science Institute.

Şata, M., Çelik, İ., Ertürk, Z., \& ve Taş, U. (2016). Akıllı Telefon Bağımlılı̆̆ı Ölçeği’nin (ATBÖ) Türk Lise Öğrencileri İçin Uyarlama Çalışması. Eğitimde ve Psikolojide Ölçme ve Değerlendirme Dergisi, 7(1), 156-169. https://doi.org/10.21031/epod.95432

Tan, E. (2013). Informal learning on YouTube: exploring digital literacy in independent online learning. Learning, Media and Technology, 38(4), 463-477. https://doi.org/10.18203/2320-6012.ijrms20170142

Taylan, H. H. (2016). Yükseköğretim Öğrencilerinde Akıllı Telefon Bağımlılığı. Retrieved from www.researchgate.net

Tavşanc1l, E., \& Aslan, E. (2001). İçerik Analizi ve Uygulama Örnekleri. Epsilon Publishing: Istanbul.

Townsend, A., M. (2000). Life in the Real Time City: Mobile Telephones and Urban Metabolism. Journal of Urban Technology, 7, 85-104. https://doi.org/10.1080/713684114

Ünal, M. H. (2015), Ankara Yıldırım Beyazıt Üniversitesi Tıp Fakültesi Öğrencilerinin Akıllı Telefon Bağımlılık Düzeylerinin Belirlenmesi, Master Thesis, Department of Family Medicine, Faculty of Medicine, Beyazit University, Ankara, Turkey.

Yıldırım, A., \& Şimşek, H. (2008). Sosyal Bilimlerde Nitel Araştırma Yöntemleri (7 $7^{\text {th }}$ Edition), Ankara: Seçkin Publishing.

Yusufoğlu, Ö. Ş. (2017). Boş Zaman Faaliyeti Olarak Akıllı Telefonlar ve Sosyal Yaşam Üzerine Etkileri: Üniversite Öğrencileri Üzerine Bir Araştırma. Journal of Human and Social Sciences Research, 6(5), 2414-243. 


\section{Copyrights}

Copyright for this article is retained by the author(s), with first publication rights granted to the journal.

This is an open-access article distributed under the terms and conditions of the Creative Commons Attribution license (http://creativecommons.org/licenses/by/4.0/). 